\title{
USING CHRONOLOGICAL ORDER: PICTURE SEQUENCE IN EFL MIDWIFERY STUDENTS' ABILITY AT STIK BINA HUSADA AND STIKES PEMBINA PALEMBANG
}

\author{
By: \\ Arief Pamuji \\ Midwifery Study Program at STIK Bina Husada Palembang, South Sumatera \\ Arief_black85@ymail.com
}

\begin{abstract}
In mastering the language, especially in writing and speaking, the students often face the problem. One of the causes is there is no appropriate method to be used. The chronological order: picture sequence is one of the good ways to overcome the problem. The objective of this research was to find out the description of the use of chronological order: picture sequence in students' ability of EFL on midwifery students at STIK Bina Husada and STIKES Pembina Palembang. The research used a descriptive quantitative design. The sample of this research was taken by using totaling sampling technique with 51 midwifery students from STIKES Pembina and STIK Bina Husada. The data were obtained from the writing and speaking test in two meetings. Then the data analysis showed that students' score of writing from both institutions got the lowest score was 60, the highest score was 88 , and the average score was 77.33. While speaking score the students got the lowest score was 65 , the highest score was 90 , and the average score was 78.35. The use of picture sequence guided them on what should they rewrite and speak based on the story. Therefore, this method leads them to more confidence in writing and speaking. From the result showed it can be concluded that most of the students were helped by using this method or way to rewrite and retell the story in the form of written and spoken.
\end{abstract}

Keywords: chronological order, writing, speaking

\section{INTRODUCTION}

English is a language that is

often taught in formal and informal

settings. Especially in schools,

English has been introduced since

elementary school and even

kindergarten to university level.
However, English for some students has become a difficult subject to learn and fear. Various kinds of factors make English difficult to understand or learn, one of which is that English is a foreign language that has many language structures. In line with Anggraini and 
Lume (2021), English is considered a difficult and scary subject for students. Developments in teaching methods are often developed so that students can be interested and have the courage to master English. Mastery of language itself consists of four abilities, namely listening, reading, writing, and speaking.

In mastering language skills, the teachers use different methods of teaching TEFL in the classroom. One of the language mastery is writing skills. Writing is a thought process translated into sentences and paragraphs.

According to Brown (2000), writing is an ability to express ideas, a feeling into the writing. Writing is communication between readers and writers who express ideas in writing so that readers understand what the author means. In writing, writers write new ideas developed through writing based on the information they get, apply goals, explore ideas, edit, sort an appropriate language, and provide information and reviews.

To develop students' writing skills, it is necessary to have a method that is very useful in teaching EFL in class offline and online, the use of chronological orders or picture sequences can be used as a student guide in rewriting news, information, and stories they have previously received.

Chronology is the organization of events based on time sequences. In literature, chronological order is writing based on the sequence of events or events. There are three types of chronological orders in writing, namely; first, Linear Narrative (Normal Chronology). Linear is what tells a story as a series of events that 
occur in time. Second, Reverse ability and consists of systematic Chronology, which tells a story from verbal messages to convey meaning. the end to the beginning, sharing Saeed Al-Sobhi and Preece (2018) events in the reverse order of their also states that speaking is the ability occurrence in time. Third, Nonlinear to speak fluently and not only Narrative. Nonlinearity is the knowledge about the features of the discrepancy of a story as a series of language, but also the ability to separate events that are told out of process information and language. In chronological order line with Brown (2004) who defines

The use of linear chronological is often used in retelling events or stories that usually use pictures or time events. With this method, the development of ideas that exist in the heads of students can be expanded and developed. Not only used in writing but chronological orders can also be applied to other language skills, namely speaking.

speaking ability as a productive skill that can be observed directly and empirically.

Based on Brown (2001), there are six categories of speaking, namely imitative, intensive, responsive, transactional, interpersonal, and broad (monologue). Imitative/Imitation is the student's ability to copy parts of the language. Intensive is imitating Speaking is the process of speech which is used to practice the conveying information produced by phonological or grammatical aspects voice or verbally. As stated by of language. Responsive is the Nunan (2004), speaking is an oral student's speech in class and short 
answers to questions or comments through the arrange pictures that they given by the teacher or students. made.

Transactional is the delivery or The difficulties that occur in exchange of specific information. students in writing and speaking can Interpersonal is used for maintaining be overcome by the method chosen social relationships rather than for by the teacher in teaching English transmitting facts and information. Foreign Language in the classroom The monologue is an oral report, both offline and online. Like the summary, and short speech.

teaching at STIKES Pembina which As with writing, speaking uses offline and STIK Bina Husada ability for students is a difficult thing. still uses online learning in the Many factors cause students difficulty learning process. The researcher speaking fluently, namely; difficulty found the difficulties of students in getting ideas to talk about, lack of the last academic year in both places mastery of vocabulary and grammar, whether in writing and speaking. The and the stages of material to be use of the appropriate method in discussed. The use of the right motivating them to make them more method can be used to facilitate fluent in the use of language. students' speaking skills. By using the

The researcher concluded that the chronological order method: picture use of Chronological order: picture sequence students can easily retell a sequence can help the researcher story that they have made before running the teaching and learning process on midwifery students of 
STIK Bina Husada and STIKES Pembina Palembang.

\section{METHODOLOGY}

The researcher used descriptive quantitative in conducting the present research. In this study, the researcher would like to find out Chronological Order: Picture Sequence in Students' Ability of EFL on Midwifery Students at STIK Bina Husada and STIKES Pembina Palembang. Because the researcher taught in both places in this semester of the academic year 2020 - 2021, so the researcher chose the midwifery students to obtain the score of students' ability score.

The researcher used the total sampling technique in this study. The study sample was from the 2nd and 4th semesters of midwifery students from STIK Bina Husada were 41 students and 2nd semester of midwifery students from STIKES Pembina was 10 students. Since the researcher taught EFL in midwifery of STIK Bina Husada and STIKES Pembina and each place was not the same number of students in the class, the researcher took the sample total was 51 from the total of the population.

To collect the data, the researcher obtained the scoring of writing and speaking in two meetings, the tests were given to the students by giving several stories and they have to comprehend and made the picture on their own then they put the picture based on the role of story. By having the pictures sequences they wrote and spoke based on it. For scoring the writing score the researcher used using a 
modified banded marking scheme

as described by Brown (2007). Meanwhile, for speaking the researcher used by Harris (1969) as speaking assessment rubric.

\section{RESULT AND DISCUSSION}

From analyzing the data, the study found the important things. There were some important findings of this study.

First, Based on the English writing score, it was found that the $2^{\text {nd }}$ semester of STIKES Pembina obtained the highest score was 86 , the lowest score was 65 , and the average score from 10 students was 77.9. The average score showed their writing was good by using the picture sequence.

Next, the $2^{\text {nd }}$ semester of STIK Bina Husada got the highest score was 86 , the lowest score was 60 , and the average score from 12 students was 75.9. It was the same as the students from STIKES Pembina and the average score of second-semester students of STIK Bina Husada showed well in their writing although there were students who got 60 .

Then the $4^{\text {th }}$ semester of STIK Bina Husada got the highest score was 88 , the lowest score was 65 , and the average score from 29 students were 77.7. It can be seen in Chart 1.

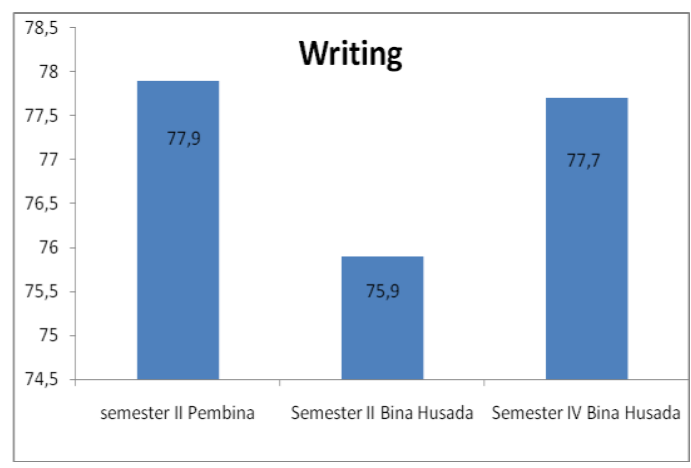

\section{Chart 1. The Result of Writing Score Based on Semester}

Second, from English speaking score, the $2^{\text {nd }}$ semester of STIKES Pembina obtained the highest score was 88 , the lowest score was 68 , and 
the average score from 10 students was 78.3.

Next, the $2^{\text {nd }}$ semester of STIK Bina Husada obtained the highest score was 88 , the lowest score was 65 , and the average score from 12 students was 77.8 .

Then the $4^{\text {th }}$ semester of STIK Bina Husada obtained the highest score was 90, the lowest score was 77 , and the average score from 29 students was 78.58. It can be seen in Chart 2.

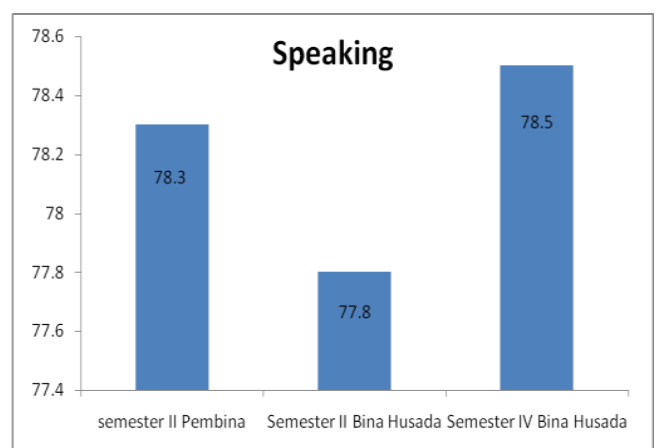

\section{Chart 2.Result of Speaking Score} Based on Semester

Third, based on the two institutions, namely STIKES Pembina and STIK Bina Husada, it was showed that STIKES Pembina obtained the highest score was 86 , the lowest score was 65 , and the average score was 77.9 in writing English. Meanwhile, STIK Bina Husada obtained the highest score was 88 , the lowest score was 60 , and the average score was 77.1. It can be seen in Chart 3.

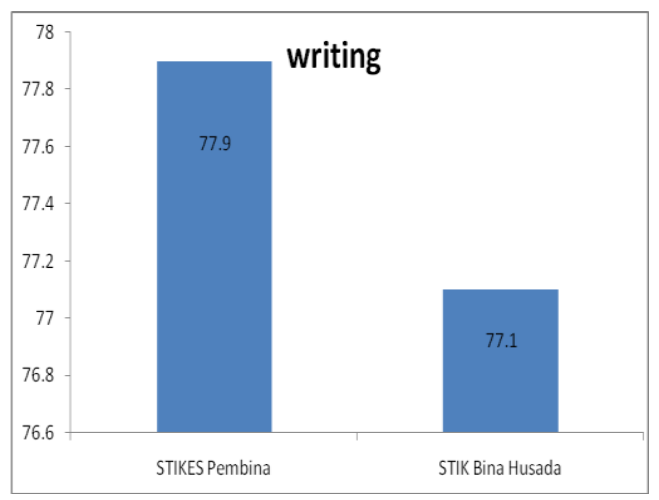

\section{Chart 3. Result of Writing Score Based on Each Institution}

Fourth, based on the two institution, namely STIKES Pembina and STIK Bina Husada, it was obtained that STIKES Pembina obtained the highest score was 86 , the lowest score was 68 , and the average score was 78.30. Meanwhile, STIK Bina Husada obtained the highest score was 90, the lowest score was 
score was 90, the lowest score was 65 , and the average score was 78.36. It can be seen in Chart 4 .

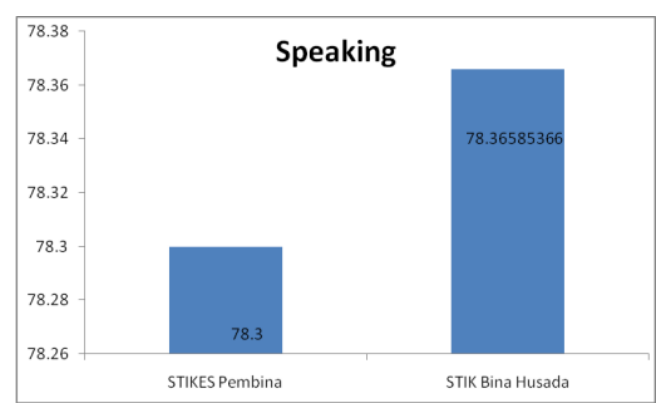

Chart 4. Result of Speaking Score Based on each Institution

Fifth, from the two institutions, namely STIKES Pembina and STIK Bina Husada, it was found that the average of writing score was 77.33 with lowest score 60 and the highest score was 88 . Meanwhile, the average score of speaking was 78.35 with lowest score was 65 and the highest was 90 . It can be seen on the chart 5 .

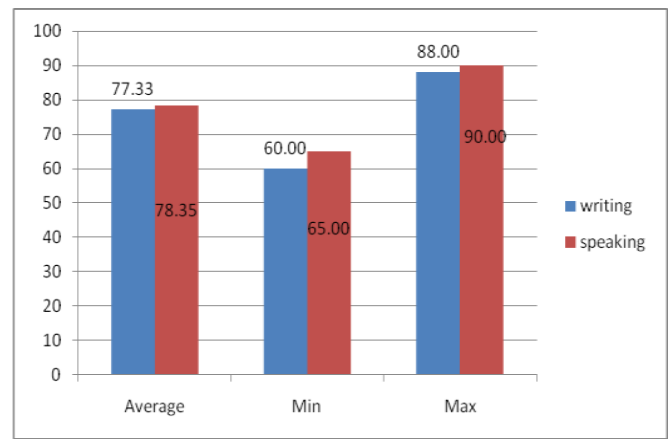

Chart 5. Result of Writing and Speaking Score from Both Institutions
To strengthen the value of this study, here are some interpretations based on the results of data analysis. Based on the results of the study, it was found that in the writing test the students used chronological order or picture sequences to help them easily in writing the paragraph. There was the lowest score that was obtained by the students during the writing test was 60 and the highest score was 88 . The use of picture sequences leads the students' writing got an average score was 77.33 .

Furthermore, for the speaking test used picture sequences, the students can show their speaking that used this method as their guide them to speak easily that obtained the lowest score was 65 , the highest score was 90, and the average score was 78.35 . 
Based on the the scoring of got a good score above 70 , by having writing and speaking test, the result this score can be concluded that using showed that most of the students were helped by using this method or way to a picture that they arrange as their rewrite and retell the story in the form of written and spoken. mapping to make the written of the story. It was the same as the writing ability test, most of their speaking also got 70, through picture sequence

\section{CONCLUSION}

In this study, the researcher aimed to determine the use of Chronological Order: Picture Sequence in Students' Ability of EFL on Midwifery Students at STIK Bina Husada and STIKES Pembina Palembang.

In this study, the researcher collected the data of writing and speaking by distributed the tests. From the data that obtained, the scoring of students from both tests showed the students got good score in their writing and speaking. In their writing ability, most of the students they had a framework as guidance to retell the story based on the picture. Some students retell the story by developed by their style but some of them were the same as the original story (sentences, words, and story event). By using the chronological order in two abilities of language lead them easily to retell the story into their writing and speaking, by having picture sequence the students have a framework or steps what the material that they had to write and speak. This method was useful to be used by a teacher in teaching English Foreign Language in offline and online 
classes. In this academic year of 2020/2021, STIKES Pembina used offline study, while STIK Bina Husada still used online learning study.

\section{REFERENCES}

Anggraini, W. P., \& Lume. (2021). The effectiveness of using chronological paragraph strategy toward students writing skill. JOLLT Journal of Languages and Language Teaching, 9(1), 77-84.

Brown, H. D. (2000). Principles of language learning and teaching. New York: Pearson Education.

Brown, H, D. (2001). Teaching by principles: an interactive approach to language pedagogy. $\left(2^{\text {nd }}\right.$ Ed). New York: Pearson Education.

Brown, H, D. (2004). Language assessment principle and classroom practices. New York: Longman.

Brown, D. (2007). Teaching by principles: An interactive approach to language pedagogy. (3 ${ }^{\text {rd }}$ Ed.). New York: Longman University Press.

Harris, D, P. (1969). Testing English as a second language. New York: McGraw-Hill.
Nunan, D. (2004). Research methods

$$
\begin{aligned}
& \text { in language teaching. } \\
& \text { Cambridge: } \\
& \text { University Press. }
\end{aligned}
$$

Saeed Al-Sobhi, B. M., \& Preece, A. S. (2018). Teaching English speaking skills to the Arab students in the Saudi School in Kuala Lumpur: Problems and solutions. International Journal of Education and Literacy Studies, 6(1), 1. Retrieved from https://doi.org/10.7575/aiac.ijels. v.6n.1p.1 